\title{
Trends in consumption of ultra-processed foods and obesity in Sweden between 1960 and 2010
}

\author{
Filippa Juul and Erik Hemmingsson* \\ Obesity Center, Karolinska University Hospital, Department of Medicine, Karolinska Institutet, Norra Stationsgatan \\ 93, SE 11364 Stockholm, Sweden
}

Submitted 21 April 2014: Final revision received 19 November 2014: Accepted 12 January 2015: First published online 25 March 2015

\begin{abstract}
Objective: To investigate how consumption of ultra-processed foods has changed in Sweden in relation to obesity.

Design: Nationwide ecological analysis of changes in processed foods along with corresponding changes in obesity. Trends in per capita food consumption during 1960-2010 were investigated using data from the Swedish Board of Agriculture. Food items were classified as group 1 (unprocessed/minimally processed), group 2 (processed culinary ingredients) or group 3 (3.1, processed food products; and $3 \cdot 2$, ultra-processed products). Obesity prevalence data were pooled from the peer-reviewed literature, Statistics Sweden and the WHO Global Health Observatory.

Setting: Nationwide analysis in Sweden, 1960-2010.

Subjects: Swedish nationals aged 18 years and older.

Results: During the study period consumption of group 1 foods (minimal processing) decreased by $2 \%$, while consumption of group 2 foods (processed ingredients) decreased by $34 \%$. Consumption of group $3 \cdot 1$ foods (processed food products) increased by $116 \%$ and group $3 \cdot 2$ foods (ultra-processed products) increased by $142 \%$. Among ultra-processed products, there were particularly large increases in soda (315\%; $22 v .92$ litres/capita per annum) and snack foods such as crisps and candies (367\%; 7 v. $34 \mathrm{~kg}$ /capita per annum). In parallel to these changes in ultra-processed products, rates of adult obesity increased from $5 \%$ in 1980 to over $11 \%$ in 2010.

Conclusions: The consumption of ultra-processed products (i.e. foods with low nutritional value but high energy density) has increased dramatically in Sweden since 1960, which mirrors the increased prevalence of obesity. Future research should clarify the potential causal role of ultra-processed products in weight gain and obesity.
\end{abstract}

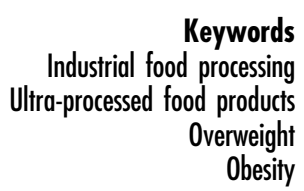

A substantial part of the foodstuffs we now consume have been industrially processed ${ }^{(1-3)}$. The concept of industrial food processing refers to all methods and techniques used by the food and drink industry to turn whole foods into food products ${ }^{(3,4)}$. Industrial processing aims to increase shelf-life, palatability and transportability of foods, and often lowers the nutritional quality while also increasing energy density ${ }^{(2)}$. Industrially produced foods referred to as ultra-processed products include ready-made snacks and sweets, soft drinks, ready-to-eat/heat products and junk food ${ }^{(3-5)}$.

Industrially processed products currently make up $75 \%$ of world food sales ${ }^{(2,6)}$. Ultra-processed foodstuffs dominate the food supply of high-income countries ${ }^{(7)}$, with relative growth being highest in the emerging markets of low- and middle-income countries ${ }^{(6,8)}$. Important drivers of this development are big transnational food and drink corporations, aggressive marketing, demographic shifts including increased female labour-force participation and delayed marriage, and changes in food behaviours such as less frequent family meals and increased snacking ${ }^{(6,8,9)}$.

The health impact of the recent dominance of industrially processed foods in the diet remains uncertain as not enough epidemiological and intervention studies specifically designed for this purpose have been carried out ${ }^{(1)}$. Nevertheless, conclusive evidence does exist for some specific processed foods: sugar-sweetened beverages are a major contributor to childhood obesity, weight gain, CVD and type 2 diabetes; industrially produced trans fats present in processed foods negatively affect cardiovascular health; 
and processed meats are associated with increased risk of mortality (CVD and cancer related) and some types of cancers ${ }^{(10-24)}$. Furthermore, observational studies have found processed junk food to be positively associated with energy intake, weight gain and insulin resistance ${ }^{(25-27)}$.

The current study aimed to investigate the consumption of ultra-processed products in Sweden from 1960 onwards and to see whether such changes were reflected in the national obesity statistics for the same time period.

\section{Methods}

\section{Data overview}

To clarify trends in processed food intake and obesity in Sweden, we pooled data from several sources; see Table 1 for an overview of data sources.

\section{Food consumption}

Data concerning direct food consumption in Sweden from 1960 onwards were obtained from the Swedish Board of Agriculture. The most recent data available at the time of latest data extraction (November 2013) were for 2010. The statistics of direct consumption presented by the Board of Agriculture are based on availability data and refer to the total quantity of food that reaches private households, restaurants and catering establishments, including those of public facilities such as schools and hospitals. Amounts consumed directly by producers are also included ${ }^{(28)}$.

Calculation and estimation methods vary for different food groups but are based mainly on national production and trade, with adjustments made for produce that is processed into other foods (e.g. meat that is used in the production of sausages, canned beef, etc.). Waste during storage and retail is accounted for, while household waste is not. Food is considered as consumed in the same calendar year it reaches consumers. Foods consumed are displayed in kilograms or litres per capita and reported in the form delivered to consumers, e.g. as fresh produce, frozen products or ready-made meals ${ }^{(28)}$.

Data are classified according to the food's original nature (i.e. as vegetables, meats, fats and oils, etc.) and each group is further divided into subgroups (e.g. the category of fats and oils is separated into butter, margarine, spreads, low-fat spreads and oils). Based on estimated consumption, the Swedish National Food Agency calculates per capita intake of energy, macronutrients and selected micronutrients. Data on the nutritional value of the per capita intake of foods are available only at the aggregation level of the food's original nature, and not separately for the different subgroups. Before 1993 calculations were performed by the Swedish Board of Agriculture ${ }^{(28)}$.

There are no data on consumption of legumes such as beans and lentils. Also, consumption of fresh fish and seafood is not reported from the year 2000 onwards as estimates were considered too unreliable by the Swedish Board of Agriculture (reasons not reported).

\section{Housebold food spending}

Information regarding household spending on food consumed within and outside the home was retrieved from Statistics Sweden's official database. The data are collected within the national Household Budget Surveys carried out by Statistics Sweden every third year. The survey includes 4000 randomly selected households representative of the Swedish population with regard to geographical living area, income groups, household size and age groups. Data collection includes three interviews and registration of all expenses for a two-week period, and is performed throughout the entire year to avoid seasonal bias ${ }^{(29,30)}$. Data in the current paper refer to the mean spending of all households. Data on expenditures on food consumed within and outside the household were available for years 1978-2009. Data collected in 2003-2009 specify spending according to type of food while data for previous years distinguish only between foods consumed within and outside the home.

\section{Obesity and overweight}

In order to present a comprehensive and complete picture of overweight and obesity in Sweden, we pooled data from the peer-reviewed literature, the nationwide database of Statistics Sweden and the WHO Global Health Observatory Data Repository ${ }^{(31-37)}$. Data of interest were mean BMI, as well as prevalence of overweight $\left(B M I \geq 25 \cdot 0 \mathrm{~kg} / \mathrm{m}^{2}\right)$ and obesity $\left(\mathrm{BMI} \geq 30 \cdot 0 \mathrm{~kg} / \mathrm{m}^{2}\right)$. We were not able to find any data on BMI or obesity before the year 1969 .

\section{Data analysis}

The data set was classified according to the NOVA system, which is based on the extent and purpose of applied industrial food processing ${ }^{(5)}$. Characteristics of the NOVA classification system are provided in Table 2.

The original food groups and subgroups were coded as group 1 (unprocessed or minimally processed foods), group 2 (processed culinary ingredients), group $3 \cdot 1$ (processed food products) or group $3 \cdot 2$ (ultra-processed products) items. Group $3 \cdot 1$ and 3.2 combined are referred to as group 3 items (ready-to-consume products). A list of the foods included in each category is provided in the online supplementary material, Supplemental Table 1 . The reclassified data were thereafter analysed to describe relative and absolute changes in consumption. For comparative purposes we also performed analyses with groups $3 \cdot 1$ and $3 \cdot 2$ combined, as several previous publication have used an earlier version of the NOVA system that does not separate between these groups ${ }^{(3,38,39)}$. Alcoholic beverages were analysed separately. 
Table 1 Overview of data sources on food consumption and purchases and prevalence of overweight and obesity in Sweden

\begin{tabular}{|c|c|c|c|c|c|}
\hline Source/author & Time period & Data & Units & Method of data collection & Study population \\
\hline \multicolumn{6}{|l|}{ Food consumption and purchases } \\
\hline Swedish Board of Agriculture ${ }^{(78)}$ & 1960-2010 & $\begin{array}{l}\text { National food consumption; } \\
\text { referring to net weight/ } \\
\text { volume excluding } \\
\text { packaging }\end{array}$ & $\begin{array}{l}\text { Kilograms or litres } \\
\text { per capita }\end{array}$ & $\begin{array}{l}\text { Statistics of production and trade; } \\
\text { special surveys for some foods (ice } \\
\text { cream, cold cut meats); statistics of } \\
\text { alcohol consumption from the } \\
\text { Social Board }\end{array}$ & Swedish population \\
\hline $\begin{array}{l}\text { Statistics Sweden; Household } \\
\text { Budget Survey (HSB) }\end{array}$ & $\begin{array}{l}\text { 1978, 1985, 1988, } \\
\text { 1992, 1995, 1996, } \\
\text { 1999-2009 }\end{array}$ & $\begin{array}{l}\text { Household expenditure on } \\
\text { food }\end{array}$ & $\begin{array}{l}\text { Swedish krona } \\
\text { (SEK) }\end{array}$ & $\begin{array}{l}\text { Household registration of all } \\
\text { expenditures during a 2-week } \\
\text { period; interviews }\end{array}$ & $\begin{array}{l}\text { Nationally representative sample of } \\
\text { randomly selected households } \\
(n 4000)\end{array}$ \\
\hline \multicolumn{6}{|l|}{ BMI, overweight and obesity } \\
\hline $\begin{array}{l}\text { Statistics Sweden; The Swedish } \\
\text { Living Conditions Survey } \\
\text { (SILC/ULF) }\end{array}$ & $\begin{array}{l}\text { 1980-81, 1988-89, } \\
\text { 1996-2010 }\end{array}$ & $\begin{array}{l}\text { Prevalence of overweight } \\
\text { and obesity; mean BMI }\end{array}$ & $\mathrm{BMI}\left(\mathrm{kg} / \mathrm{m}^{2}\right)$ & $\begin{array}{l}\text { Face-to-face/telephone interviews; } \\
\text { self-reported height and weight }\end{array}$ & $\begin{array}{l}\text { Nationally representative sample of } \\
\text { Swedes aged } 16 \text { years and older } \\
(n 13000-15000)\end{array}$ \\
\hline Berg et al. ${ }^{(31)}$ & $\begin{array}{l}1985,1990,1995 \\
2002\end{array}$ & $\begin{array}{l}\text { Prevalence of overweight } \\
\text { and obesity; mean BMI }\end{array}$ & BMI $\left(\mathrm{kg} / \mathrm{m}^{2}\right)$ & $\begin{array}{l}\text { Cross-sequential population-based } \\
\text { surveys; measured height and } \\
\text { weight }\end{array}$ & $\begin{array}{l}\text { Adults (25-64 years; } n 1000-1600) \text { in } \\
\text { Gothenburg, south-west Sweden }\end{array}$ \\
\hline Lilja et al. ${ }^{(32)}$ & $\begin{array}{l}1986,1990,1994 \\
1999,2004\end{array}$ & $\begin{array}{l}\text { Prevalence of overweight } \\
\text { and obesity }\end{array}$ & BMI $\left(\mathrm{kg} / \mathrm{m}^{2}\right)$ & $\begin{array}{l}\text { Cross-sequential population-based } \\
\text { surveys; measured height and } \\
\text { weight }\end{array}$ & $\begin{array}{l}\text { Adults (25-64 years; } n 500) \text { in } \\
\text { northern Sweden }\end{array}$ \\
\hline Neovius et al. ${ }^{(33)}$ & $2002,2006,2010$ & $\begin{array}{l}\text { Prevalence of overweight } \\
\text { and obesity; mean BMI }\end{array}$ & BMI $\left(\mathrm{kg} / \mathrm{m}^{2}\right)$ & $\begin{array}{l}\text { Cross-sequential population-based } \\
\text { surveys; self-reported height and } \\
\text { weight }\end{array}$ & $\begin{array}{l}\text { Men and women (18-64 years; } \\
n 30 \text { 000) in Stockholm }\end{array}$ \\
\hline $\begin{array}{l}\text { WHO Global Health } \\
\text { Observatory } \\
\text { Data Repository }{ }^{(36)}\end{array}$ & $1980-2010$ & Mean BMI & $\mathrm{BMI}\left(\mathrm{kg} / \mathrm{m}^{2}\right)$ & $\begin{array}{l}\text { Population-based surveys and } \\
\text { surveillance systems; measured } \\
\text { height and weight }\end{array}$ & No information available \\
\hline Neovius et al. ${ }^{(34)}$ & 1969-2005 & Prevalence of obesity & $\mathrm{BMI}\left(\mathrm{kg} / \mathrm{m}^{2}\right)$ & $\begin{array}{l}\text { Military Service Conscription } \\
\text { Registry; measured height and } \\
\text { weight }\end{array}$ & $\begin{array}{l}\text { Swedish military conscripts; approx. } \\
82 \% \text { of all Swedish men of } \\
\text { conscription age ( } 18 \text { years) }\end{array}$ \\
\hline Kark and Rasmussen ${ }^{(37)}$ & 1970-2000 & $\begin{array}{l}\text { Prevalence of overweight } \\
\text { and obesity; mean BMI }\end{array}$ & BMI $\left(\mathrm{kg} / \mathrm{m}^{2}\right)$ & $\begin{array}{l}\text { Military Service Conscription } \\
\text { Registry; measured height and } \\
\text { weight }\end{array}$ & $\begin{array}{l}\text { Swedish military conscripts; approx. } \\
82 \% \text { of all Swedish men of } \\
\text { conscription age ( } 18 \text { years) }\end{array}$ \\
\hline
\end{tabular}


Table 2 Food classification according to extent and purpose of industrial food processing. Characteristics of each food group and examples of included foodstuffs

\begin{tabular}{|c|c|c|}
\hline Food group & Processing & Examples \\
\hline $\begin{array}{l}\text { 1. Unprocessed or } \\
\text { minimally } \\
\text { processed } \\
\text { foods }\end{array}$ & $\begin{array}{l}\text { No processing or mainly physical processing in } \\
\text { ways that do not add any substances. May } \\
\text { include subtraction of parts of the food in ways } \\
\text { that do not significantly affect the food's use. } \\
\text { Minimal processing includes cleaning, portioning, } \\
\text { grating, flaking, drying, chilling, freezing, } \\
\text { pasteurizing, bottling, gas and vacuum packing, } \\
\text { packaging and fat reduction. Non-alcoholic } \\
\text { malting and fermentation are also considered } \\
\text { minimal processing }\end{array}$ & $\begin{array}{l}\text { Fresh, chilled, frozen, vacuum-packed fruits, } \\
\text { vegetables, fungi, roots and tubers; grains } \\
\text { (cereals) in general; fresh, frozen and dried } \\
\text { beans and other pulses (legumes); dried fruits } \\
\text { and } 100 \% \text { non-reconstituted and unsweetened } \\
\text { fruit juices; unsalted nuts and seeds; fresh, dried } \\
\text { and chilled frozen meats, poultry and fish; fresh } \\
\text { and pasteurized milk, fermented milk such as } \\
\text { plain yoghurt; eggs; teas, coffee, herb infusions, } \\
\text { tap water, bottled spring water }\end{array}$ \\
\hline $\begin{array}{l}\text { 2. Processed } \\
\text { culinary } \\
\text { ingredients }\end{array}$ & $\begin{array}{l}\text { Extraction and purification by industry of } \\
\text { constituents of a whole food, or else obtained } \\
\text { from nature (e.g. salt). Processes include milling, } \\
\text { pressing and pulverizing, and may involve the } \\
\text { use of stabilizing or purifying agents as well as } \\
\text { other additives }\end{array}$ & $\begin{array}{l}\text { Vegetable oils; animal fats such as butter, cream } \\
\text { and lard; sugar, syrups and sweeteners in } \\
\text { general; salt; starches, flours, 'raw' pastas and } \\
\text { noodles made from flour and water }\end{array}$ \\
\hline $\begin{array}{l}\text { 3.1. Processed food } \\
\text { products }\end{array}$ & $\begin{array}{l}\text { Processing of whole foods by the addition of } \\
\text { substances such as oil, sugar or salt to increase } \\
\text { attractiveness, durability or palatability, resulting } \\
\text { in products that are recognizable as versions of } \\
\text { the original foods. Processes include canning } \\
\text { and bottling using oils, sugars or syrups, or salt, } \\
\text { and methods of preservation such as salting, salt } \\
\text { pickling, smoking and curing }\end{array}$ & $\begin{array}{l}\text { Canned or bottled vegetables and pulses (legumes) } \\
\text { preserved in brine; peeled or sliced fruits } \\
\text { preserved in syrup; canned fish preserved in oil } \\
\text { or brine; salted nuts; non-mixed and un- } \\
\text { reconstituted processed meat and fish (e.g. ham, } \\
\text { bacon and smoked fish); cheese }\end{array}$ \\
\hline $\begin{array}{l}\text { 3.2. Ultra-processed } \\
\text { products }\end{array}$ & $\begin{array}{l}\text { Processing of substances derived from foods } \\
\text { by e.g. baking, frying, extruding, moulding, } \\
\text { re-shaping, hydrogenation and hydrolysis. } \\
\text { Generally include a large number of additives } \\
\text { such as preservatives, sweeteners, sensory } \\
\text { enhancers, colorants, flavours and processing } \\
\text { aids, but little or no whole food. May be fortified } \\
\text { with micronutrients. The aim is create durable, } \\
\text { convenient and palatable ready-to-eat or ready- } \\
\text { to-heat food products suitable to be consumed as } \\
\text { snacks or to replace freshly prepared food-based } \\
\text { dishes and meals }\end{array}$ & $\begin{array}{l}\text { Biscuits (cookies), cakes and pastries; ice cream; } \\
\text { jams (preserves); chocolates, confectionery } \\
\text { (candies), cereal bars, breakfast cereals with } \\
\text { added sugar; chips, crisps; sauces; savoury and } \\
\text { sweet snack products; sugared fruit and milk } \\
\text { drinks, sugared and non-caloric cola, and other } \\
\text { soft drinks; pre-prepared pizza and pasta, meat, } \\
\text { poultry, fish and vegetable dishes; chicken } \\
\text { nuggets, hot dogs, sausages, burgers, fish sticks; } \\
\text { canned or dehydrated soups and noodles; infant } \\
\text { formulas, follow-on milks and baby food }\end{array}$ \\
\hline
\end{tabular}

Correct classification according to degree of processing was not possible when subgroups in the original data contained a mix of group 1, 2 and 3 foods. The category of fermented dairy products includes both natural (group 1) and flavoured products (group 3). As Swedes traditionally consume unflavoured fermented dairy products, in particular buttermilk (filmjölk), this category was assigned to group 1. Mustard (group 3.2) is reported in the category of spices (group 2) and was therefore classified as a processed culinary ingredient. Natural fruit and vegetable juices (group 1) could not be separated from sweetened juices or fruit punches (group 3.2), for which all were classified as ultra-processed food products. Finally, the category of almonds and nuts was allocated to group 1 although it includes both natural (group 1) and toasted and salted varieties (group 3·1).

Furthermore, trends in energy and macronutrient intakes as well as in household expenses on food for home consumption and eating outside the home were investigated. Data on mean BMI, overweight and obesity from different sources were compiled into charts according to sex and age.

\section{Results}

\section{Trends in food consumption according to degree of industrial processing}

Trends in per capita consumption of group 1, 2, 3.1 and 3.2 foods in Sweden from 1960 to 2010 are shown in Fig. 1. During this period consumption of unprocessed and minimally processed foods (group 1) decreased by $2 \%$ (397v. $387 \mathrm{~kg} /$ capita per annum) and consumption of processed culinary ingredients (group 2) decreased by $34 \%$ (69 v. $45 \mathrm{~kg} /$ capita per annum). In contrast, the consumption of processed food products (group 3.1) increased by $116 \%$ (23v. $51 \mathrm{~kg} /$ capita per annum) and the consumption of ultra-processed products (group 3.2) rose by $142 \%$ (125 v. $302 \mathrm{~kg} /$ capita per annum). The relative increase of group 3 foods combined was 138\% (148v. $352 \mathrm{~kg} /$ capita per annum).

The largest relative increase among ultra-processed products occurred for ready-made soups and sauces ( $1147 \%$ ), with an annual per capita consumption of 21 litres in 2010 compared with 1.8 litres in 1960 (Fig. 2(a)). Intake of carbonated sugar- or artificially sweetened sodas and 


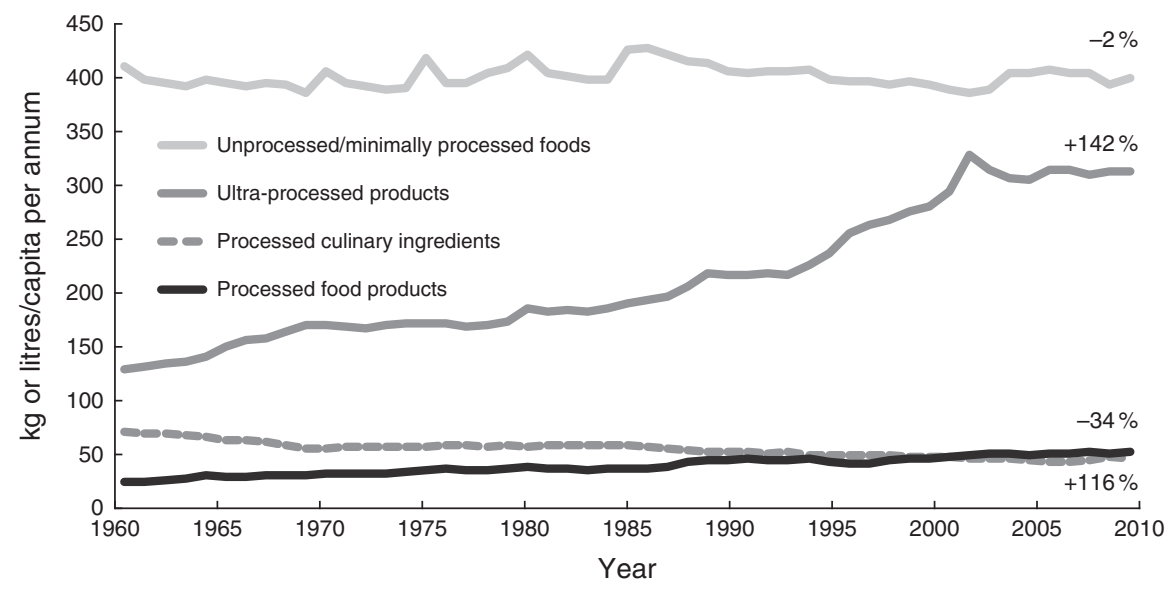

Fig. 1 Annual per capita consumption (kilograms or litres) of food and non-alcoholic beverages in Sweden, 1960-2010, according to degree of industrial food processing by the NOVA framework

(a)

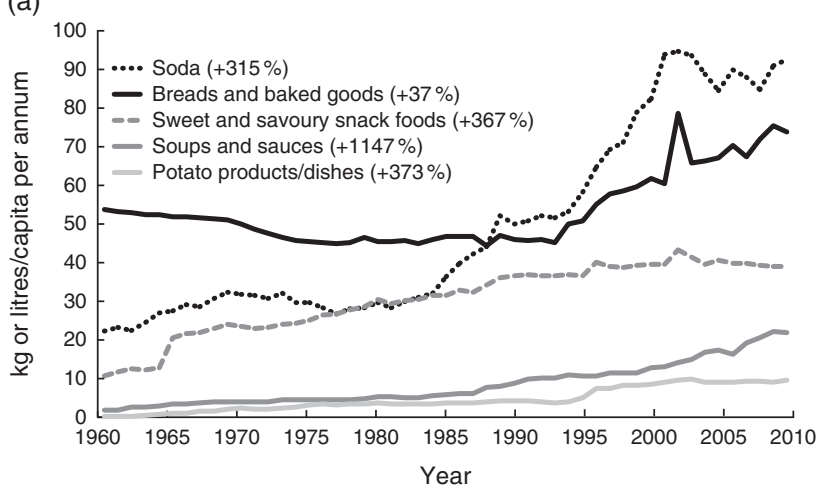

(c)

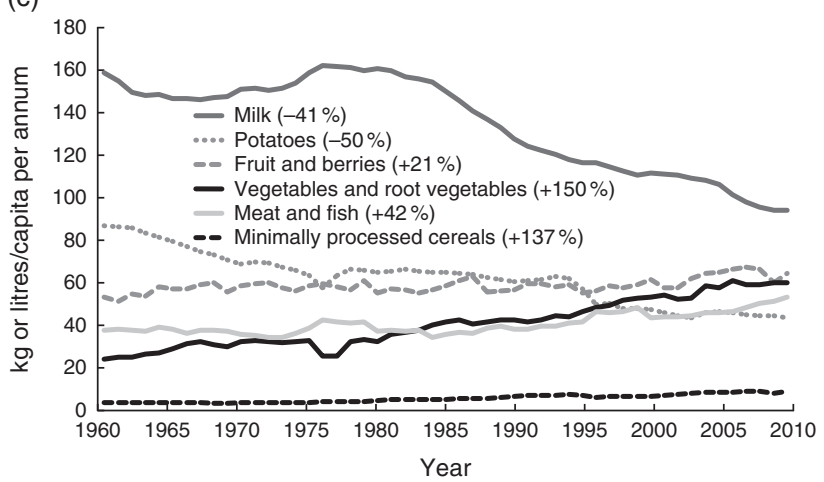

(b)

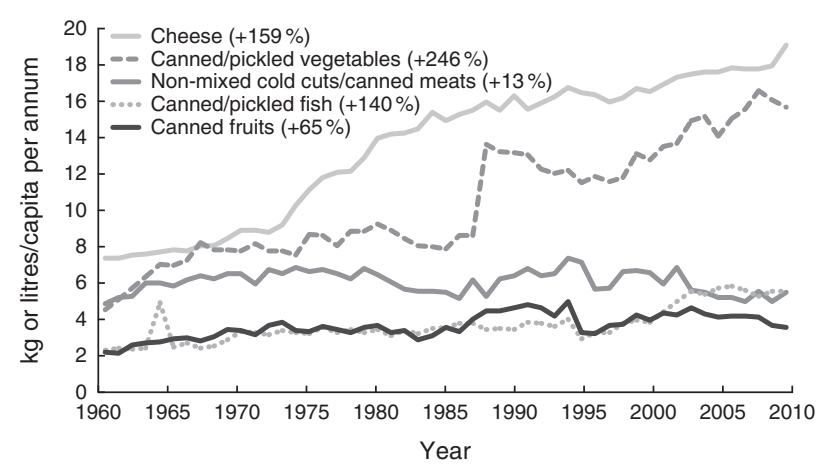

(d)

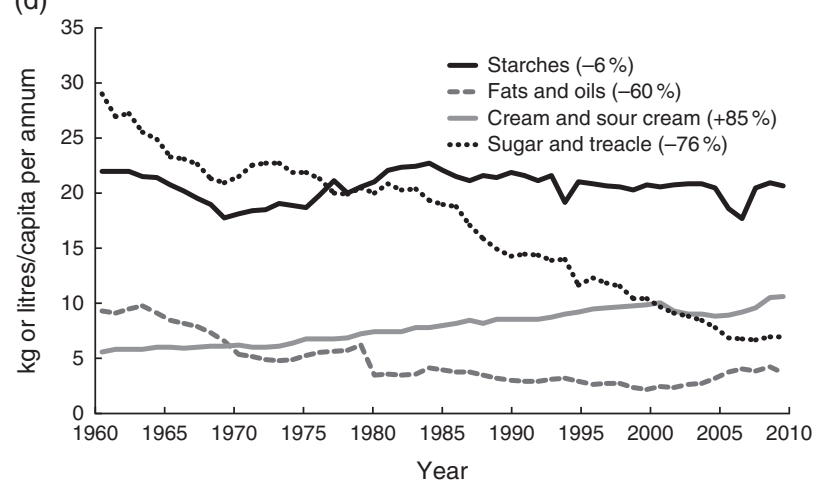

Fig. 2 Annual per capita consumption (kilograms or litres) of selected group 1, 2, 3.1 and 3.2 foods in Sweden for years 1960-2010. (a) Ultra-processed products (group 3.2): 'breads and baked goods' include all types of breads, pizza, pastries, cookies, cakes and biscuits; 'potato products/dishes' include refrigerated, frozen and dehydrated products such as ready-made potato-salad, frozen French fries and instant mashed potato mixes; 'soda' refers to caloric and non-caloric flavoured carbonated beverages such as colas, diet sodas and ciders; 'soups and sauces' refer to ready-made refrigerated, frozen, canned and dehydrated soups and sauces; 'sweet and savoury snack foods' include potato and corn crisps, popcorn, candies, chocolate, ice cream and chocolate milk. (b) Processed food products (group 3.2): 'cheese' includes hard and soft varieties, both fresh and cured; 'canned/pickled vegetables' refer to vegetables that have been pickled or canned in brine; 'canned fruits' refer to fruits canned in syrup; 'canned/ pickled fish' refer to fish and seafood that have been pickled and/or canned, salted or smoked; 'non-mixed cold cuts/canned meats' refer to items such as ham and canned meats. (c) Unprocessed and minimally processed foods (group 1): data refer to fresh and frozen meat, fish, vegetables, fruits and berries; fresh milk including whole-fat, semi-skimmed and skimmed varieties; fresh eggs; fresh potatoes; minimally processed grains including rice, oatmeal and other cereals. (d) Processed culinary ingredients: 'starches' include uncooked pasta and noodles, flours, cake and bread mixes, cereal-based formula mixes and potato starch; cream and sour cream; 'fats and oils' include butter and plant oils; 'sugar and treacle' include brown sugar 
(a)

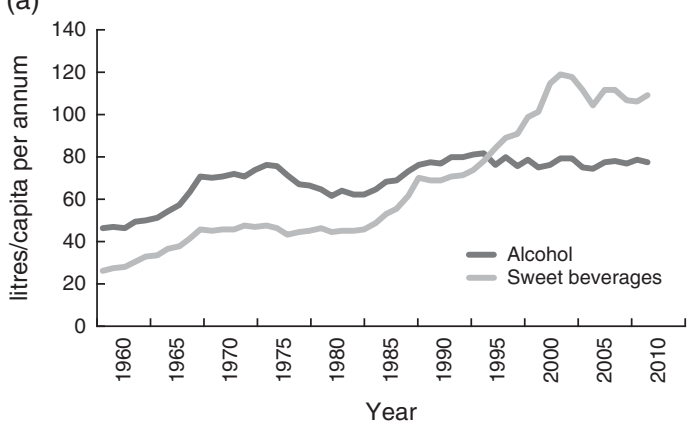

(c)

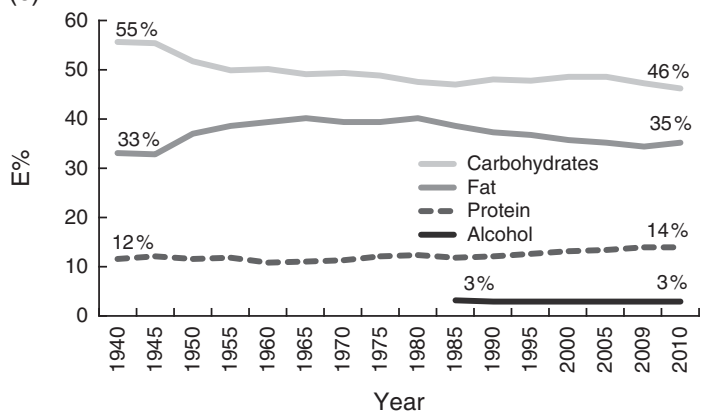

(b)

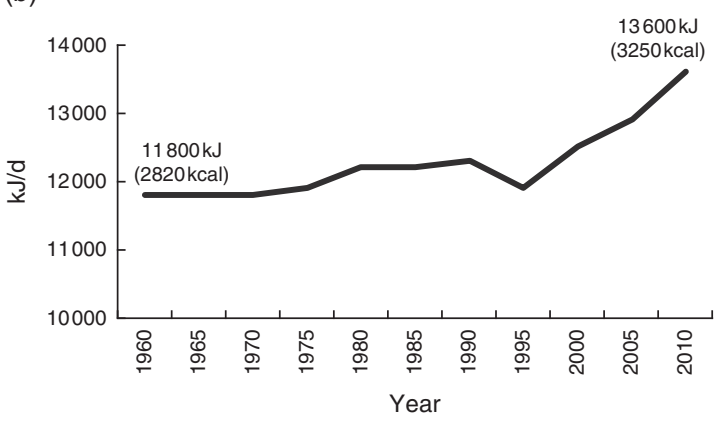

(d)

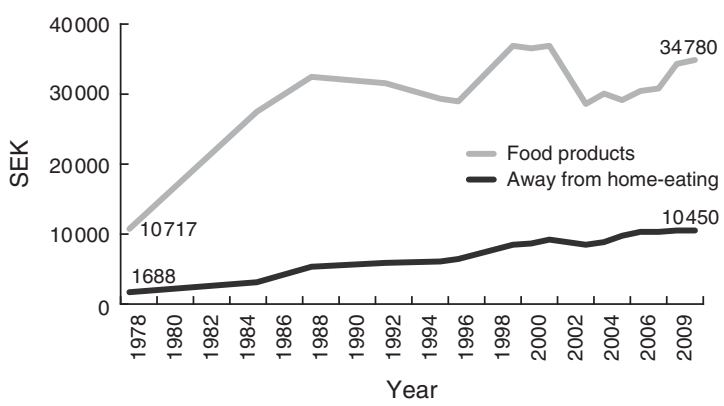

Fig. 3 (a) Annual per capita consumption (litres) of alcohol and caloric/non-caloric sweet beverages in Sweden, 1960-2010. (b) Mean daily per capita energy intake (kJ) in Sweden, 1960-2010. (c) Relative contribution of macronutrients to total energy intake (E\%) in Sweden, 1960-2010. (d) Average annual household expenditure (Swedish krona, SEK) on food products and awayfrom-home eating in Sweden, 1978-2009

ciders rose by $315 \%$, from 22 to 92 litres/capita per annum. Thus, the increase of soft drinks alone accounted for $40 \%$ of the absolute increase in consumption of ultra-processed products between 1960 and 2010. Simultaneously, the consumption of juices and other non-carbonated sweet fruit drinks rose by $342 \%$, from 3.7 to $16 \cdot 2$ litres/capita per annum. Consumption of all sweet drinks combined peaked in 2002 at 119 litres/capita and declined slightly thereafter, reaching 109 litres/capita in 2010 (Fig. 3(a)).

Furthermore, the consumption of sweet and savoury snack foods such as candies, chocolate and crisps/potato chips increased by $367 \%$ during the study period, from $7.4 \mathrm{~kg}$ to $34.5 \mathrm{~kg} / \mathrm{capita}$ per annum. Intake of ready-made potato dishes such as frozen French fries and instant mashed potatoes also increased substantially (374\%; $0.2 v$. $9.6 \mathrm{~kg} /$ capita per annum). Consumption of breads and baked goods including pizza, cookies and biscuits rose by $38 \%$ (67 v. $78 \mathrm{~kg} /$ capita per annum; Fig. 2(a)). Ultraprocessed meat products and ready-made dishes containing meat increased by $66 \%$, from 17 to $28 \mathrm{~kg} /$ capita per annum (data not shown). Intake of ultra-processed fruit products such as jams and jellies increased by $158 \%$, from $3 \cdot 0$ to $7 \cdot 8 \mathrm{~kg} /$ capita per annum (data not shown).

Intake of all processed food products (group 3.1) increased during the study period (Fig. 2(b)). The largest increases in this group were seen for consumption of canned and/or pickled vegetables $(246 \% ; 4.5 v .11 .7 \mathrm{~kg} /$ capita per annum) and cheese (159\%; 7.4 v. $19 \mathrm{~kg} / \mathrm{capita}$ per annum). Consumption of canned fruits increased by $65 \%(2 \cdot 2 v .3 .6 \mathrm{~kg} / \mathrm{capita}$ per annum) and intake of canned, pickled and smoked fish and seafood increased by $53 \%(4.5 v \cdot 6.8 \mathrm{~kg} /$ capita per annum). The lowest relative increase was seen for non-mixed cold cuts such as ham and canned meats (13\%; $4.8 v .5 .5 \mathrm{~kg} /$ capita per annum).

Consumption of fresh/frozen fruits, berries and vegetables, minimally processed cereals and fresh/frozen meat and fish all increased during the study period (Fig. 2(c)). There was an increased annual consumption of fermented dairy products $(325 \% ; 7.7 v .32 .7$ litres/capita) and nuts ( $140 \% ; 1 \cdot 1$ v. $2.7 \mathrm{~kg} /$ capita; data not shown). In contrast, intake of fresh potatoes decreased by $50 \%$ (from 86.8 to $43.3 \mathrm{~kg} /$ capita per annum) and milk consumption declined by $41 \%$ (from 158.3 to 93.7 litres/capita per annum). Egg consumption decreased minimally, from $10 \cdot 8$ to $10 \cdot 6 \mathrm{~kg} /$ capita per annum $(-2 \%)$, while consumption increased for honey (133\%; $0.3 v .0 .7 \mathrm{~kg} /$ capita per annum) and coffee and tea $(14.5 \% ; 8.3 v .9 .5 \mathrm{~kg} /$ capita per annum).

Among processed culinary ingredients (Fig. 2(d)) the most significant decline in consumption occurred for sugar and treacle $(-76 \% ; 29.0$ v. $6.9 \mathrm{~kg} /$ capita per annum). Intake of fats and oils decreased by $60 \%$ and consumption of starches including flours and pastas declined by $6 \%$. In contrast, consumption of cream and sour cream increased by $90 \%$, reaching 10.6 litres/capita in 2010 . Consumption of salt and spices increased by $13 \%$, from $3.1 \mathrm{~kg}$ to $3.5 \mathrm{~kg} /$ capita per annum (data not shown). 
Intake of alcoholic beverages (Fig. 3(a)) rose by $67 \%$ between 1960 and 2010 (46.3 v. 77.3 litres/capita) mostly due to greater consumption of wine $(623 \% ; 3 \cdot 3 v .23 \cdot 7$ litres/capita). Beer consumption rose by $36 \%$ (37.2 v. $50 \cdot 7$ litres/capita) while liquor consumption fell by $50 \%(5 \cdot 7 v$. $2 \cdot 9$ litres/capita).

\section{Trends in energy intake}

Daily per capita energy intake, as estimated from the direct consumption of food, increased by $15 \%$ from $11800 \mathrm{MJ}$ (2820 kcal) in 1960 to $13600 \mathrm{MJ}$ (3250 kcal) in 2010 (Fig. 3(b)). Relative energy from carbohydrates decreased from $55 \%$ to $46 \%$ of total energy, while percentage of energy from protein and fat increased (from $12 \%$ and $33 \%$ to $14 \%$ and $36 \%$, respectively; Fig. 3(c)). Alcohol provided $3 \%$ of daily energy from 1985 onwards.

\section{Trends in bousebold food expenses}

Total average annual household food expenses increased between 1978 and 2010 (Fig. 3(d)). However, the relative spending on food decreased from $20 \%$ of total household expenditures in 1985 to $13 \%$ in 2009. In parallel, the spending on meals outside the home (e.g. at restaurants, cafeterias and fast-food establishments) increased from $10 \%$ of total food expenses in 1985 to $23 \%$ in $2009^{(29)}$.

\section{Trends in overweight and obesity}

Figure 4(a)-(f) describes overweight (BMI $\geq 25 \cdot 0 \mathrm{~kg} / \mathrm{m}^{2}$ ) and obesity (BMI $\geq 30 \cdot 0 \mathrm{~kg} / \mathrm{m}^{2}$ ) prevalence and mean BMI for Swedish adults from 1980 to 2010. In 1980, 35\% of Swedish men had a BMI $\geq 25.0 \mathrm{~kg} / \mathrm{m}^{2}$ and $4.5 \%$ were obese $^{(35)}$. In 2008 the corresponding figures were 54-56\% and $11 \%$, respectively ${ }^{(33,35)}$. During the same period prevalence of overweight among females increased from $26 \%$ to $39 \%$ while obesity among women rose from $5 \%$ to $10 \%{ }^{(35)}$. In parallel, mean BMI increased from 24.8 to $26.7 \mathrm{~kg} / \mathrm{m}^{2}$ for men and from 24.6 to $25 \cdot 5 \mathrm{~kg} / \mathrm{m}^{2}$ for women ${ }^{(35)}$.

From 1970 to 2000, the prevalence of overweight $\left(B M I=25 \cdot 0-29 \cdot 9 \mathrm{~kg} / \mathrm{m}^{2}\right)$ among Swedish conscripts more than doubled $(6.6 \% v .13 .6 \%)$ while obesity prevalence increased from $1.0 \%$ to $3.5 \%$ (Fig. $4(\mathrm{~g} \text { ) and (h) })^{(37)}$. Moreover, between 1970 and 2000 average BMI rose from 20.9 to $22.5 \mathrm{~kg} / \mathrm{m}^{2}$, and there was a tenfold increase in morbid obesity $\left(\mathrm{BMI} \geq 35 \cdot 0 \mathrm{~kg} / \mathrm{m}^{2}\right)$ from 1969 to 2005 $(0 \cdot 1 \% v \cdot 1 \cdot 3 \%)^{(34,37)}$.

\section{Discussion}

\section{Main findings}

The current study provides a unique description of changes in industrially processed food consumption in Sweden from 1960 until 2010. While consumption of minimally processed foods was unchanged during the study period, consumption of ready-to-consume products (group 3) rose considerably. In particular, there was a remarkable increase in the intake of ultra-processed products (group $3 \cdot 2$ ), clearly showing the transition from eating freshly prepared meals from nutritious foods to ready-to-consume ultra-processed products that are nutritionally imbalanced.

In parallel, adult overweight and obesity rates rose significantly, with notable increases in severe obesity. While causation cannot be proven through ecological time-trend data, the current study nevertheless supports a link between the much-increased intake of ultra-processed products and the obesity epidemic.

\section{Previous studies}

Previous reports have documented the increased presence of ready-to-consume products (group 3 items) in the global food system and diet, particularly in the form of ultraprocessed products. By analysing data from nationally representative food expenditure surveys Moubarac et al. found that ready-to-consume products on average contributed $61.7 \%$ of daily energy in Canada, with ultraprocessed products accounting for $54.9 \%$ of daily energy ${ }^{(40)}$. In Brazil, mean energy percentage from ultraprocessed products increased from $18.7 \%$ in 1987 to $29.6 \%$ in 2009 , according to national household survey data $^{(41)}$. In Northern and Central Europe, $50-56 \%$ of daily energy is consumed in the form of highly processed foodstuffs (using a slightly different definition than the current paper: 'Foods that have been industrially prepared, including those from bakeries and catering outlets, and which require no or minimal domestic preparation apart from heating and cooking') ${ }^{(1)}$.

Due to the low price of vegetable oils, fats, starches, sugars and salt, ultra-processed products are highly profitable for food producers and available to consumers at a low cost, which, along with aggressive marketing, including to children, contributes to the high consumption $^{(42)}$. Over time, price disparity between healthy unprocessed or minimally processed whole foods and ultra-processed products has increased, making a diet of fruit, vegetables, fish and meat more expensive than one high in refined grains, added sugar and added fats ${ }^{(43,44)}$.

\section{Implications for public bealth}

Ultra-processed products and diets based on such items tend to be unhealthy and unbalanced: excessive in fat (including saturated and trans fat), free sugars and sodium while low in dietary fibre, micronutrients and phytochemicals $^{(4,38,45,46)}$. Moubarac et al. found that compared with the population quintile with the lowest consumption of group 3 items (33.2\% of total energy), the diet of those in the highest quintile ( $84.5 \%$ of total energy) was significantly lower in protein (11.6 v. 14.9\%) and fibre (8.0 $v$. $11.2 \mathrm{~g} / 4184 \mathrm{~kJ}(1000 \mathrm{kcal}))$, higher in fat $(38.2 v .35 \%)$, free sugars $(9.2 v .15 \%)$ and sodium $(1.1 v .1 .6 \mathrm{~g} / 4184 \mathrm{~kJ})$, and more energy dense $(7.5 v .9 .6 \mathrm{~kJ} / \mathrm{g}(1.8 v .2 .3 \mathrm{kcal} / \mathrm{g}))^{(38)}$.

Likewise, consumption of foods from outside-the-home sources is associated with higher energy intakes, lower 
(a)

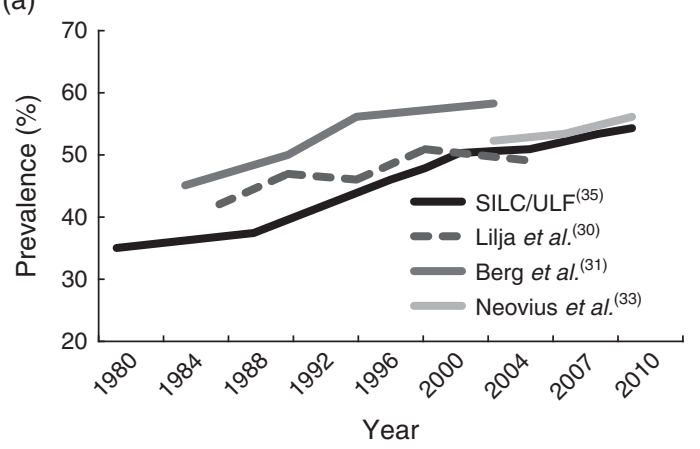

(c)

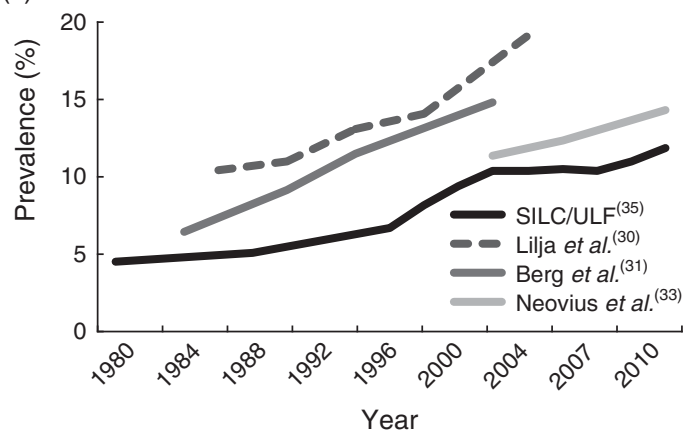

(e)

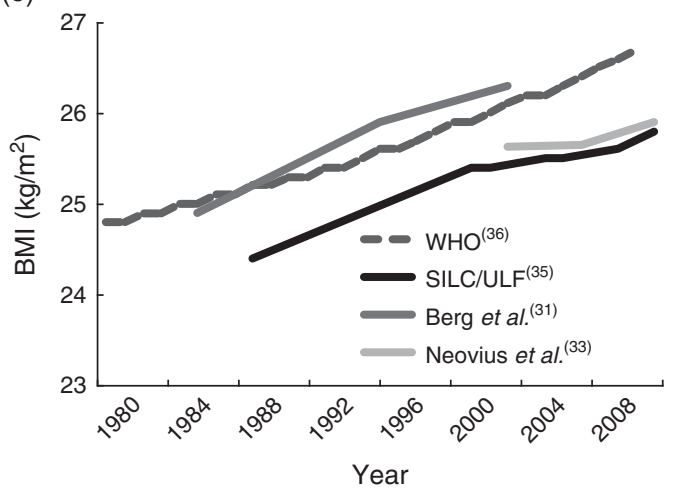

(g)

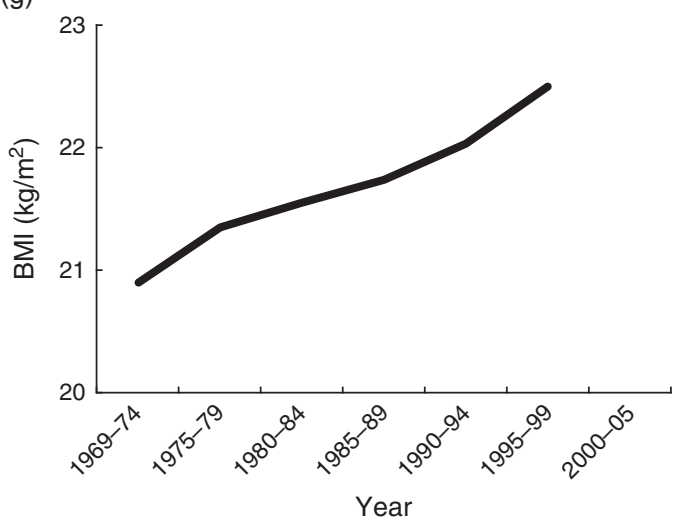

(b)

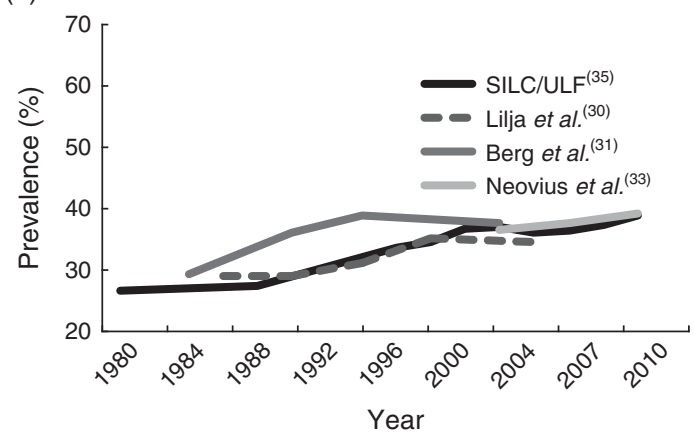

(d)

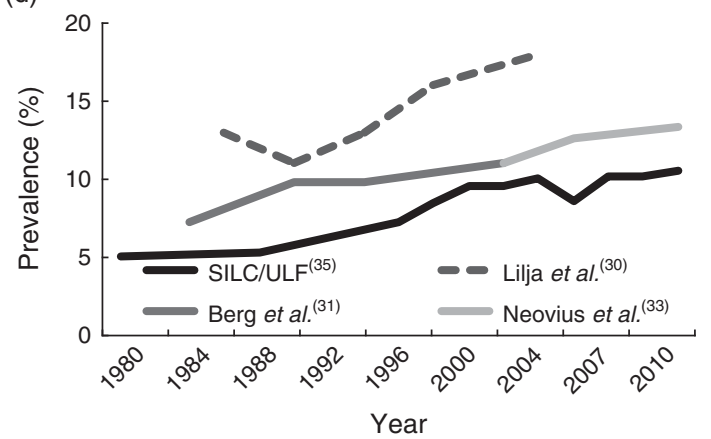

(f)

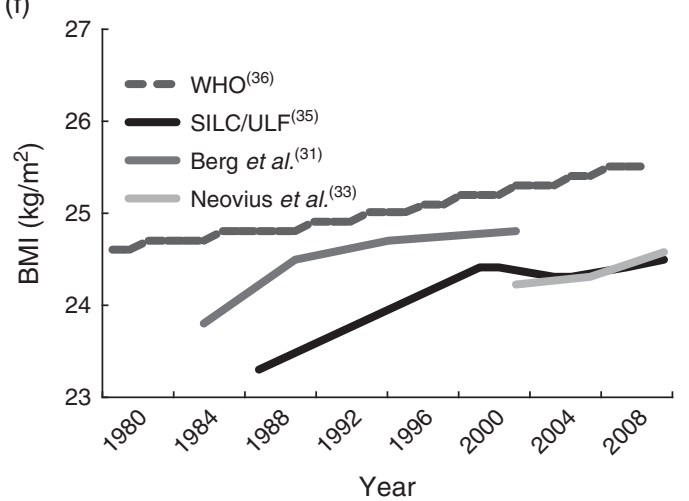

(h)

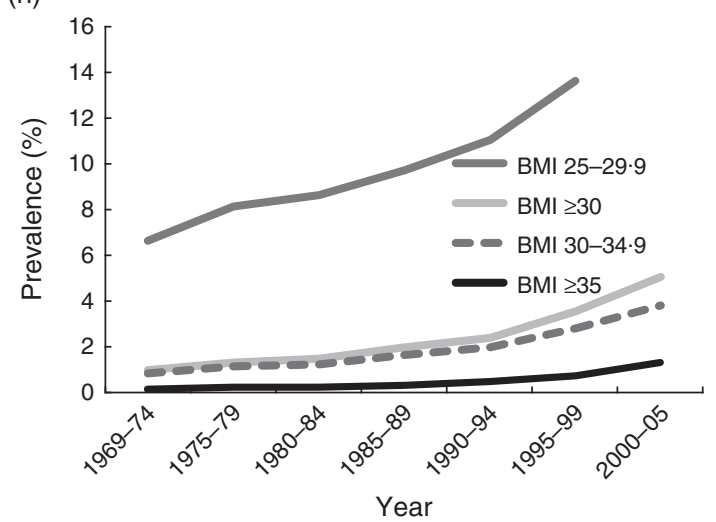

Fig. 4 Overweight and obesity in Sweden. (a) Prevalence of overweight $\left(\mathrm{BMI} \geq 25.0 \mathrm{~kg} / \mathrm{m}^{2}\right)$ among adult men in Sweden, 1980-2010. (b) Prevalence of overweight (BMI $\geq 25.0 \mathrm{~kg} / \mathrm{m}^{2}$ ) among adult women in Sweden, 1980-2010. (c) Prevalence of obesity $\left(B M I \geq 30.0 \mathrm{~kg} / \mathrm{m}^{2}\right.$ ) among adult men in Sweden, 1980-2010. (d) Prevalence of obesity (BMI $\left.\geq 30.0 \mathrm{~kg} / \mathrm{m}^{2}\right)$ among adult women in Sweden, 1980-2010. (e) Mean BMI of adult men in Sweden, 1980-2010. (f) Mean BMI of adult women in Sweden, 1980-2010. (g) Mean BMl of male conscripts in Sweden, 1969-2005. (h) Prevalence of overweight and obesity among male conscripts in Sweden, 1969-2005 
nutritional quality and weight gain ${ }^{(47-51)}$. A study in Guatemala found that each $10 \%$ increase in the share of the household food budget spent on highly processed foods was associated with a $4.3 \%$ higher BMI of family members and greater risk of overweight and obesity ${ }^{(52)}$. In a cross-sectional study of 210 Brazilian adolescents, intake of ready-to-consume products (group 3) was significantly associated with presence of the metabolic syndrome ${ }^{(39)}$. More recent studies differentiating between processed food products (group 3.1) and ultra-processed products (group 3.2) suggest that it may in particular be the consumption of the latter that is associated with negative health effects. In a nationally representative sample of the Brazilian population, Canella et al. ${ }^{(53)}$ observed significant and positive associations between household availability of ultra-processed products (group 3.2), expressed as quartiles of dietary energy availability, and average BMI and prevalence of excess weight and obesity. Processed food products (group 3.1) availability, on the other hand, was not associated with obesity outcomes ${ }^{(53)}$. Similarly, increased consumption of ultra-processed products such as sugar-sweetened beverages, potato chips, French fries, processed meats and refined grains was strongly and positively associated with weight gain in a large US prospective study. In contrast, there was an inverse association between weight gain and increased intake of vegetables, fruits, nuts, yoghurt and whole grains ${ }^{(54)}$.

Studies have found Western-style dietary patterns, high in refined and ultra-processed products such as soft drinks, processed meat products, fast food including hamburgers, pizza and French fries, refined breads and pastries, and sweet and savoury snack foods, to be associated with inferior quality of life, depression and anxiety, and with mental health problems in adolescents ${ }^{(55-59)}$. Some authors argue that foods highly refined by industrial processing may be addictive and cause substance abuse-like conditions ${ }^{(60)}$. In contrast, observational studies link cooking and eating meals prepared from whole foods with higher intakes of fruit, vegetables and whole grains, increased survival, better overall health and lower BMI ${ }^{(61-66)}$.

\section{Potential mechanisms bebind increased consumption of ultra-processed foods and obesity}

Ultra-processed products are omnipresent, convenient and aggressively marketed, which has been shown to increase frequent snacking, eating while watching television or working and intake of liquid energy in large quantities (e.g. sodas) ${ }^{(67-70)}$. Presumably, the high energy density and palatability of ultra-processed products ${ }^{(4,38,45)}$, in combination with associated eating behaviours, undermine normal energy homeostasis and appetite control, resulting in overconsumption and increasing the likelihood of obesity ${ }^{(46,70)}$.

Processing allows foods to be eaten faster, which leads to lower satiation and higher energy intakes as the short oral sensory exposure time provides insufficient cues for satiation $^{(67)}$. Furthermore, diets high in ultra-processed products may reduce total energy expenditure due to lower diet-induced thermogenesis. In an experimental study average postprandial energy expenditure was $50 \%$ lower after eating highly processed foods, compared with isoenergetic whole foods. The low fibre and nutrient density and high content of simple carbohydrates of ultraprocessed products are believed to account for this discrepancy ${ }^{(71)}$.

An additional concern is the increased cumulative intake of artificial ingredients and additives such as preservatives, colorants, chemical flavorings and non-caloric sweeteners. Consumption of industrially produced trans fats, common in ultra-processed products such as cookies and fried foods, is associated with weight gain and abdominal obesity, and increase the risk of CHD and type 2 diabetes $^{(45)}$.

Furthermore, observational data link daily intake of artificially sweetened soda with incident metabolic syndrome including obesity, type 2 diabetes, stroke and kidney function decline ${ }^{(72-74)}$. A recent review suggests that sugar alcohols, artificial sweeteners and fructose may contribute to obesity and metabolic abnormalities by modulating the gut microbiota, leading to enhanced energy extraction, intestinal inflammation and endotoxaemia ${ }^{(75)}$.

Research also indicates that monoacylglycerides (preservatives), saccharin (artificial sweetener) and bisphenol A (common in food and beverage containers) may contribute to weight gain by stimulating basal insulin secretion, thereby increasing food intake and insulin resistance $^{(76)}$. Furthermore, in vitro studies suggest that the food additives sodium sulfite, sodium benzoate and curcumin may promote obesity by decreasing leptin secretion $^{(77)}$.

\section{Meaning for policy makers}

The association between increased consumption of ultraprocessed products and obesity warrants further research. Well-designed studies are needed to determine causality and identify potential mechanisms. Given the muchincreased consumption of non-natural chemical additives present in ultra-processed products, there is an urgent need to clarify the safety of consuming such products.

Given what is now known about the harms of ultraprocessed products, combined with the alarming increase in consumption, national dietary guidelines should dissuade consumption of nutritionally deficient ultra-processed products and emphasize the benefits of nutrient-dense whole foods prepared from scratch. Public food programmes and catering establishments at schools, hospitals and workplaces for example may likewise benefit from minimizing ultra-processed products, which are nutritionally imbalanced and promote unhealthy eating behaviours and overconsumption, in favour of meals and dishes based on freshly prepared foods.

Finally, taxation of ultra-processed products such as sodas, as well as subsidies for healthy whole foods, may 
contribute to reversing the trend of ever-increasing dependence on ultra-processed products. The marketing of ultra-processed products should also be scrutinized and more strictly regulated.

\section{Strengths and limitations}

Strengths of the current investigation include the use of systematically collected, nationwide and long-term trend data. This enabled a unique assessment of secular trends in ultra-processed product consumption in Sweden from a time point before the obesity epidemic started. As data were based on statistics of production and trade there was no recall or report bias. The NOVA framework for food classification according to degree of industrial processing was another advantage as it permitted identification of important changes in consumption patterns that are not evident using traditional food classifications of macronutrients ${ }^{(4)}$.

However, there are several limitations to the study. An important limitation is that our data refer to food availability and not actual consumption. In consequence, they may not provide a completely accurate reflection of the Swedish diet. In particular, total food consumption was likely overestimated, as spoilage at household level is not accounted for. Because unprocessed and minimally processed foods are more perishable than most processed culinary ingredients, processed food products and ultraprocessed products, group 1 foods may account for a larger proportion of household waste and likely more overestimated in relation to group 2, 3.1 and $3 \cdot 2$ items.

Moreover, secular data of per capita intake do not provide information on the diet of individuals or of different population segments. Neither do they allow differentiation of consumption between private households and private and public food outlets. Hence, potential differences in amounts and types of food consumed at home and elsewhere, and among different population groups, cannot be known. In addition, our data were limited to large-scale production sectors and do not include food production from caterers.

Furthermore, data were restricted to weight and volume of foods. Importantly, the energetic and nutritional contribution of foods was specified only according to the major food groups based on food's original nature. Due to this limitation of the data we were unable to perform analysis regarding the energetic and nutritional contribution of each food group of the NOVA system over time, which would have been preferable. Likewise, data on household spending on food did not distinguish between different types of foods for the majority of the study period. Trends in food expenses for each group of the NOVA system could therefore not be analysed.

Fresh fish and seafood were not reported for the years 2000-2010. Changes in the consumption of these foods can therefore not be determined, which affects the longitudinal comparability of consumption of group 1 foods. Furthermore, the entry of Sweden into the European
Union in 1995 affected consumption estimates for some food groups due to changes in the statistics of production and trade and in nomenclature. Other revisions of nomenclature and methodology have also occurred, hampering year-to-year comparability of specific food groups. However, changed allocation of a food from one subgroup to another should not materially affect the current analysis as long as the food remains within the same level of processing, which is likely the case.

Finally, since we did not have access to individual-level data on food and obesity, we were not able to perform an analysis of association with appropriate adjustment for confounding variables.

\section{Conclusion}

Consumption of ultra-processed products increased dramatically in Sweden from 1960 to 2010, which closely tracked the increased prevalence of obesity. Of special note is the considerably increased intake of energy-dense and nutritionally empty snack foods such as candies and crisps, and of sodas and other sweet beverages. Future research is needed to clarify the potential role of ultra-processed products in obesity and public health.

\section{Acknowledgements}

Financial support: This research received no specific grant from any funding agency in the public, commercial or not-for-profit sector. Conflict of interest: None. Authorship: F.J. was responsible for study conception, data acquisition, analysis and interpretation of the data, drafting of the manuscript, statistical analysis, critical revision of the manuscript for important intellectual content, and had primary responsibility for the final content. E.H. was responsible for analysis and interpretation of the data, statistical analysis, critical revision of the manuscript for important intellectual content, and study supervision. Ethics of buman subject participation: Not applicable.

\section{Supplementary material}

To view supplementary material for this article, please visit http://dx.doi.org/10.1017/S1368980015000506

\section{References}

1. Slimani N, Deharveng G, Southgate DA et al. (2009) Contribution of highly industrially processed foods to the nutrient intakes and patterns of middle-aged populations in the European Prospective Investigation into Cancer and Nutrition study. Eur J Clin Nutr 63, Suppl. 4, S206-S225.

2. Stuckler D \& Nestle M (2012) Big food, food systems, and global health. PLoS Med 9, e1001242. 
3. Moubarac JC, Claro RM, Baraldi LG et al. (2013) International differences in cost and consumption of ready-to-consume food and drink products: United Kingdom and Brazil, 20082009. Glob Public Health 8, 845-856.

4. Monteiro CA, Levy RB, Claro RM et al. (2010) A new classification of foods based on the extent and purpose of their processing. Cad Saude Publica 26, 2039-2049.

5. Moubarac J-C, Parra D, Cannon G et al. (2014) Food classification systems based on food processing: significance and implications for policies and actions. A systematic literature review and assessment. Curr Obes Rep 3, 256-272.

6. Moodie R, Stuckler D, Monteiro C et al. (2013) Profits and pandemics: prevention of harmful effects of tobacco, alcohol, and ultra-processed food and drink industries. Lancet 381, 670-679.

7. Monteiro CA, Moubarac JC, Cannon G et al. (2013) Ultraprocessed products are becoming dominant in the global food system. Obes Rev 14, Suppl. 2, 21-28.

8. Monteiro CA \& Cannon G (2012) The impact of transnational 'big food' companies on the South: a view from Brazil. PLoS Med 9, e1001252.

9. Smith LP, Ng SW \& Popkin BM (2013) Trends in US home food preparation and consumption: analysis of national nutrition surveys and time use studies from 1965-1966 to 2007-2008. Nutr J 12, 45.

10. Hu FB (2013) Resolved: there is sufficient scientific evidence that decreasing sugar-sweetened beverage consumption will reduce the prevalence of obesity and obesity-related diseases. Obes Rev 14, 606-619.

11. Malik VS, Schulze MB \& Hu FB (2006) Intake of sugarsweetened beverages and weight gain: a systematic review. Am J Clin Nutr 84, 274-288.

12. Malik VS, Popkin BM, Bray GA et al. (2010) Sugar-sweetened beverages, obesity, type 2 diabetes mellitus, and cardiovascular disease risk. Circulation 121, 1356-1364.

13. Hu FB \& Malik VS (2010) Sugar-sweetened beverages and risk of obesity and type 2 diabetes: epidemiologic evidence. Physiol Behav 100, 47-54.

14. Moreno LA \& Rodriguez G (2007) Dietary risk factors for development of childhood obesity. Curr Opin Clin Nutr Metab Care 10, 336-341.

15. Bachman CM, Baranowski T \& Nicklas TA (2006) Is there an association between sweetened beverages and adiposity? Nutr Rev 64, 153-174.

16. Vartanian LR, Schwartz MB \& Brownell KD (2007) Effects of soft drink consumption on nutrition and health: a systematic review and meta-analysis. Am J Public Health 97, 667-675.

17. Faramawi MF, Johnson E, Fry MW et al. (2007) Consumption of different types of meat and the risk of renal cancer: meta-analysis of case-control studies. Cancer Causes Control 18, $125-133$

18. Hu J, La Vecchia C, Morrison H et al. (2011) Salt, processed meat and the risk of cancer. Eur I Cancer Prev 20, 132-139.

19. Kris-Etherton PM, Lefevre M, Mensink RP et al. (2012) Trans fatty acid intakes and food sources in the US population: NHANES 1999-2002. Lipids 47, 931-940.

20. Rohrmann S, Overvad K, Bueno-de-Mesquita HB et al. (2013) Meat consumption and mortality - results from the European Prospective Investigation into Cancer and Nutrition. BMC Med 11, 63.

21. Sinha R, Cross AJ, Graubard BI et al. (2009) Meat intake and mortality: a prospective study of over half a million people. Arch Intern Med 169, 562-571.

22. Mozaffarian D, Aro A \& Willett WC (2009) Health effects of trans-fatty acids: experimental and observational evidence. Eur J Clin Nutr 63, Suppl. 2, S5-S21.

23. Ganguly R \& Pierce GN (2012) Trans fat involvement in cardiovascular disease. Mol Nutr Food Res 56, 1090-1096.

24. Bendsen NT, Christensen R, Bartels EM et al. (2011) Consumption of industrial and ruminant trans fatty acids and risk of coronary heart disease: a systematic review and meta-analysis of cohort studies. Eur J Clin Nutr 65, 773-783.

25. Pereira MA, Kartashov AI, Ebbeling CB et al. (2005) Fastfood habits, weight gain, and insulin resistance (the CARDIA study): 15-year prospective analysis. Lancet 365, 36-42.

26. Schroder H, Fito M \& Covas MI (2007) Association of fast food consumption with energy intake, diet quality, body mass index and the risk of obesity in a representative Mediterranean population. Br J Nutr 98, 1274-1280.

27. Bowman SA \& Vinyard BT (2004) Fast food consumption of US adults: impact on energy and nutrient intakes and overweight status. J Am Coll Nutr 23, 163-168.

28. Eidstedt MW \& Christina (2012) Consumption of Food and Nutritive Values, Data up to 2010. Statistical Report no. 2012:01. Jönköping: Swedish Board of Agriculture.

29. Statistics Sweden (2010) Household Budget Survey (HSB). http://www.scb.se/en_/Finding-statistics/Statistics-by-subjectarea/Household-finances/Household-expenditures/Householdbudget-survey-HBS/ (accessed June 2013).

30. Statistics Sweden (2010) Household Budget Survey (HBS) 2007-2009, Expenditure and Income Report. Stockholm: Statistics Sweden.

31. Berg C, Rosengren A, Aires N et al. (2005) Trends in overweight and obesity from 1985 to 2002 in Goteborg, West Sweden. Int J Obes (Lond) 29, 916-924.

32. Lilja M, Eliasson M, Stegmayr B et al. (2008) Trends in obesity and its distribution: data from the Northern Sweden MONICA Survey, 1986-2004. Obesity (Silver Spring) 16, 1120-1128.

33. Neovius K, Johansson K, Kark M et al. (2013) Trends in selfreported BMI and prevalence of obesity 2002-10 in Stockholm County, Sweden. Eur J Public Health 23, 312-315.

34. Neovius M, Teixeira-Pinto A \& Rasmussen F (2008) Shift in the composition of obesity in young adult men in Sweden over a third of a century. Int J Obes (Lond) 32, 832-836.

35. Statistics Sweden (2013) Living Conditions Surveys (ULF/SILC). http://www.scb.se/en_/Finding-statistics/Statisticsby-subject-area/Living-conditions/Living-conditions/LivingConditions-Surveys-ULFSILC/ (accessed June 2013).

36. WHO Global Health Observatory Data Repository (n.d.) Overweight/Obesity: Mean body mass index trends (crude estimate) by country. http://apps.who.int/gho/data/node. main.A903?lang=en (accessed June 2013).

37. Kark M \& Rasmussen F (2005) Growing social inequalities in the occurrence of overweight and obesity among young men in Sweden. Scand J Public Health 33, 472-477.

38. Moubarac JC, Martins AP, Claro RM et al. (2013) Consumption of ultra-processed foods and likely impact on human health. Evidence from Canada. Public Health Nutr 16, 2240-2248.

39. Tavares LF, Fonseca SC, Garcia Rosa ML et al. (2012) Relationship between ultra-processed foods and metabolic syndrome in adolescents from a Brazilian Family Doctor Program. Public Health Nutr 15, 82-87.

40. Moubarac J-C, Batal M, Martins AP et al. (2014) Processed and ultra-processed food products: consumption trends in Canada from 1938 to 2011. Can J Diet Pract Res 75, 15-21.

41. Martins AP, Levy RB, Claro RC et al. (2013) Increased contribution of ultra-processed food products in the Brazilian diet (1987-2009). Rev Saude Publica 47, 1-10.

42. Monteiro CA (2009) Nutrition and health. The issue is not food, nor nutrients, so much as processing. Public Health Nutr 12, 729-731.

43. Drewnowski A (2004) Obesity and the food environment: dietary energy density and diet costs. Am J Prev Med 27, 3 Suppl., 154-162.

44. Monsivais P \& Drewnowski A (2007) The rising cost of lowenergy-density foods. J Am Diet Assoc 107, 2071-2076.

45. Astrup A, Dyerberg J, Selleck M et al. (2008) Nutrition transition and its relationship to the development of obesity and related chronic diseases. Obes Rev 9, Suppl. 1, 48-52. 
46. Ludwig DS (2011) Technology, diet, and the burden of chronic disease. JAMA 305, 1352-1353.

47. Nielsen SJ, Siega-Riz AM \& Popkin BM (2002) Trends in energy intake in US between 1977 and 1996: similar shifts seen across age groups. Obes Res 10, 370-378.

48. Guthrie JF, Lin BH \& Frazao E (2002) Role of food prepared away from home in the American diet, 1977-78 versus 1994-96: changes and consequences. J Nutr Educ Behav 34, 140-150.

49. Prentice AM \& Jebb SA (2003) Fast foods, energy density and obesity: a possible mechanistic link. Obes Rev 4, 187-194.

50. Duffey KJ, Gordon-Larsen P, Jacobs DR Jr et al. (2007) Differential associations of fast food and restaurant food consumption with 3-y change in body mass index: the Coronary Artery Risk Development in Young Adults Study. Am J Clin Nutr 85, 201-208.

51. Thompson OM, Ballew C, Resnicow K et al. (2004) Food purchased away from home as a predictor of change in BMI z-score among girls. Int J Obes Relat Metab Disord 28, 282-289.

52. Asfaw A (2011) Does consumption of processed foods explain disparities in the body weight of individuals? The case of Guatemala. Health Econ 20, 184-195.

53. Canella DS, Levy RB, Martins AP et al. (2014) Ultraprocessed food products and obesity in Brazilian households (2008-2009). PLoS One 25, e92752.

54. Mozaffarian D, Hao T, Rimm EB et al. (2011) Changes in diet and lifestyle and long-term weight gain in women and men. $N$ Engl J Med 364, 2392-2404.

55. Ruano C, Henriquez $\mathrm{P}$, Martinez-Gonzalez MA et al. (2013) Empirically derived dietary patterns and healthrelated quality of life in the SUN project. PLOS One $\mathbf{8}$, e61490.

56. Jacka FN, Mykletun A, Berk M et al. (2011) The association between habitual diet quality and the common mental disorders in community-dwelling adults: the Hordaland Health study. Psychosom Med 73, 483-490.

57. Bakhtiyari M, Ehrampoush E, Enayati N et al. (2013) Anxiety as a consequence of modern dietary pattern in adults in Tehran - Iran. Eat Behav 14, 107-112.

58. Jacka FN, Rothon C, Taylor S et al. (2013) Diet quality and mental health problems in adolescents from East London: a prospective study. Soc Psychiatry Psychiatr Epidemiol 48, 1297-1306.

59. Jacka FN, Kremer PJ, Berk M et al. (2011) A prospective study of diet quality and mental health in adolescents. PLOS One 6, e24805.

60. Ifland JR, Preuss HG, Marcus MT et al. (2009) Refined food addiction: a classic substance use disorder. Med Hypotheses 72, 518-526.

61. Larson NI, Perry CL, Story M et al. (2006) Food preparation by young adults is associated with better diet quality. $J \mathrm{Am}$ Diet Assoc 106, 2001-2007.

62. McLaughlin C, Tarasuk V \& Kreiger N (2003) An examination of at-home food preparation activity among low-income, food-insecure women. J Am Diet Assoc 103, 1506-1512.
63. Laska MN, Larson NI, Neumark-Sztainer D et al. (2012) Does involvement in food preparation track from adolescence to young adulthood and is it associated with better dietary quality? Findings from a 10-year longitudinal study. Public Health Nutr 15, 1150-1158.

64. Zick CD, Stevens RB \& Bryant WK (2011) Time use choices and healthy body weight: a multivariate analysis of data from the American Time Use Survey. Int J Behav Nutr Phys Act 8, 84 .

65. Kolodinsky JM \& Goldstein AB (2011) Time use and food pattern influences on obesity. Obesity (Silver Spring) 19, 2327-2335.

66. Chen RC, Lee MS, Chang YH et al. (2012) Cooking frequency may enhance survival in Taiwanese elderly. Public Health Nutr 15, 1142-1149.

67. de Graaf C (2006) Effects of snacks on energy intake: an evolutionary perspective. Appetite 47, 18-23.

68. Robinson TN (1999) Reducing children's television viewing to prevent obesity: a randomized controlled trial. JAMA 282, $1561-1567$.

69. Mattes R (2006) Fluid calories and energy balance: the good, the bad, and the uncertain. Physiol Behav 89, 66-70.

70. Monteiro CA, Levy RB, Claro RM et al. (2011) Increasing consumption of ultra-processed foods and likely impact on human health: evidence from Brazil. Public Health Nutr 14, 5-13.

71. Barr SB \& Wright JC (2010) Postprandial energy expenditure in whole-food and processed-food meals: implications for daily energy expenditure. Food Nutr Res 2010, 54.

72. Bernstein AM, de Koning L, Flint AJ et al. (2012) Soda consumption and the risk of stroke in men and women. $\mathrm{Am}$ J Clin Nutr 95, 1190-1199.

73. Lin J \& Curhan GC (2011) Associations of sugar and artificially sweetened soda with albuminuria and kidney function decline in women. Clin J Am Soc Nephrol 6, 160-166.

74. Nettleton JA, Lutsey PL, Wang Y et al. (2009) Diet soda intake and risk of incident metabolic syndrome and type 2 diabetes in the Multi-Ethnic Study of Atherosclerosis (MESA). Diabetes Care 32, 688-694.

75. Payne AN, Chassard C \& Lacroix C (2012) Gut microbial adaptation to dietary consumption of fructose, artificial sweeteners and sugar alcohols: implications for host-microbe interactions contributing to obesity. Obes Rev 13, 799-809.

76. Corkey BE (2012) Diabetes: have we got it all wrong? Insulin hypersecretion and food additives: cause of obesity and diabetes? Diabetes Care 35, 2432-2437.

77. Ciardi C, Jenny M, Tschoner A et al. (2012) Food additives such as sodium sulphite, sodium benzoate and curcumin inhibit leptin release in lipopolysaccharide-treated murine adipocytes in vitro. Br J Nutr 107, 826-833.

78. Swedish Board of Agriculture (2012) Consumption of food. http://statistik.sjv.se/Dialog/varval.asp?ma=DK06\&ti= Direktkonsumtion\&path=../Database/Jordbruksverket/ Konsumtion av livsmedel\%28ej officiell statistik\%29/\&lang=2 (accessed May 2013). 